\title{
Polypharmacy in community-based older adults: results of the Fibra study
}

Priscila de Paula Marques' (DD Daniela de Assumpção' ${ }^{1}$ Roseli Rezendel (ID) Anita Liberalesso Neri' (ID) Priscila Maria Stolses Bergamo Franciscol ${ }^{1}$

\section{Abstract}

Objectives: To estimate the prevalence of polypharmacy among older adults ( $\geq 65$ years); to verify its association with sociodemographic variables, nutritional status and health conditions; to describe the prevalence of polypharmacy according to the presence of specific chronic diseases, and to report the method of acquiring drugs. Method: A cross-sectional study was performed with older adults $(n=2,217)$ from seven Brazilian municipal regions. The prevalence of polypharmacy and its $95 \%$ confidence intervals were estimated. Associations were verified using Pearson's Chi-squared test with a significance level of $5 \%$, and the independent associations between the selected variables and polypharmacy were verified by multiple hierarchical Poisson regression. Results: The prevalence of polypharmacy was 18.4\% (CI95\%:16.8-20.0), and was significantly lower among non-white individuals, those who did not have a health plan, and those who assessed their health as very good/good ( $p<0.05)$. Obesity: (PR=1.36; CI95\%:1.06-1.75), increased waist circumference ( $\mathrm{PR}=1.54$; $\mathrm{CI} 95 \%: 1.08-2.20)$ and presence of two $(\mathrm{PR}=2.24$; CI95\%:1.52-3.31) or three or more ( $\mathrm{PR}=4.22$; CI95\%:2.96-6.02) chronic diseases were positively associated with polypharmacy. Polypharmacy was observed in about $30.0 \%$ of older adults with heart disease, diabetes mellitus and/or strokes/CVA/ischemia. The frequency of older adults who acquired drugs in Basic Health Units was $20.3 \%$ and those who obtained them via their own/family resources was $13.5 \%$. Conclusion: Among older adults, the identification of segments with a higher prevalence of polypharmacy enables a better structuring of the provision of treatment during their care pathway, allowing special attention to be paid to problems related to the use of drugs.

\footnotetext{
Universidade Estadual de Campinas, Faculdade de Ciências Médicas, Programa de Pós-graduação em Gerontologia. Campinas, SP, Brasil.
}

Keywords: Health of the Elderly. Aging. Polypharmacy. Chronic Disease.

The authors declare there are no conflicts of interest in relation to the present study.

No funding was received in relation to the present study. 


\section{INTRODUCTION}

Aging is a dynamic and progressive process that involves morphological, functional and biochemical disorders, with older adults frequently presenting simultaneous dysfunctions in different organs or systems ${ }^{1}$. Data from the National Health Survey (or PNS) show that $54.1 \%$ of older adults (60 years and over) had a chronic disease, $47.1 \%$ two such illnesses and $33.2 \%$ three or more ${ }^{2}$. With the occurrence of multiple chronic diseases, there is a significant increase in the simultaneous use of five or more drugs (polypharmacy) $)^{3-5}$, the prevalence rates of which are 13.0, 37.0 and $60.0 \%$ in Brazilian older adults with two, three and four or more diseases, respectively ${ }^{6}$.

Drugs play a central role in health treatment and recovery and are one of the most important items in the health care of older adults, however, even in necessary situations, the simultaneous use of several drugs can trigger serious complications ${ }^{1,7}$. Pharmacological redundancy, inappropriate medication prescriptions, potentially dangerous drug interactions, the increased risk and severity of adverse reactions, cumulative toxicity, iatrogenesis, lower adherence to treatment, and hospitalizations and deaths are widely reported in literature ${ }^{8-14}$. Physiological changes in aging such as weight loss, the reduction of lean mass and increased fat mass increase the risk of adverse reactions ${ }^{1}$.

Given the high prevalence of chronic diseases in older adults and the risks associated with the overuse of drugs ${ }^{8,12}$, the definition of polypharmacy into specific subgroups may contribute to improving the pharmaceutical care offered in health services, improving patients' understanding of treatment and consequently, increasing therapeutic success ${ }^{9,10,13}$.

The objective of the present study was therefore to estimate the prevalence of polypharmacy in older adults (65 years of age or older); verify its association with sociodemographic variables, nutritional status and health conditions; describe the prevalence of polypharmacy according to the presence of specific chronic diseases, and report the method of acquiring the drugs.

\section{METHOD}

A cross-sectional study was performed with data from the Brazilian Older Adults Frailty (Fibra) survey, conducted between 2008 and 2009, with those aged 65 years and older residing in the urban areas of seven Brazilian cities.

Ninety census tracts were drawn in Campinas (São Paulo); 93 in Belém (Pará); 75 in Poços de Caldas (Minas Gerais); 62 in Ermelino Matarazzo (São Paulo); 60 in Campina Grande (Paraíba); 60 in Parnaíba (Piauí) and 27 in Ivoti (Rio Grande do Sul). For each location, male and female quotas were estimated by age group (65-69, 70-74, 75-79, and $\geq 80$ years), based on the percentage distribution of these segments in the older adult populations living in urban areas ${ }^{15}$.

For Campinas and Belém, cities with more than one million inhabitants, a minimum sample size of 601 older people was estimated, considering a sampling error of 4 percentage points. For the other cities, which had less than one million inhabitants, samples of 384 older adults were estimated, with an error of 5\%. In Ivoti, where 646 older people lived, the estimate was 235 people, with a sampling error of $5 \% 0^{15}$.

Subsequently, older adults were recruited in their homes through an approach by pairs of duly trained and identified interviewers. The recruiters visited all the households in the census tracts drawn to identify older adults who met the inclusion criteria: age $\geq 65$ years, understand the instructions, agree to participate in the survey, and be a permanent resident in the household. The exclusion criteria were the presence of problems with memory, attention, spatial and temporal orientation and communication, which were suggestive of cognitive deficits; permanent or temporary disability in walking (except those who used walking aids); localized loss of strength and aphasia as a result of stroke sequelae; severe impairment of motricity, speech or affectivity related to Parkinson's disease; severe hearing or visual impairment; and terminal stage disease $\mathrm{s}^{15}$. The inclusion and exclusion criteria were based on Fried et al. ${ }^{16}$ and Ferrucci et al. ${ }^{17}$. 
Data were collected through a previously tested instrument, with validated questions, in a single meeting at defined locations, such as schools, churches, primary healthcare units, clubs and social centers. Undergraduate and postgraduate students received previous training in the application of the questionnaire on different days and times, which lasted from 40 to 120 minutes $^{15}$. Older adults were informed about the research objectives and confidentiality of individual data, and were asked to sign a Free and Informed Consent Form.

The first part of data collection was organized into five blocks related to demographic and socioeconomic, anthropometric, blood pressure, frailty and cognitive screening variable data, each administered by an interviewer. Upon completing the last block of the first phase, the interviewer checked the score of the older adult on the Mini Mental State Examination (MMSE) to exclude those with cognitive impairment. The second part of data collection was performed with older adults who achieved a score higher than the MMSE cutoff score of 17 for illiterate individuals; 22 for those with one to four years of study; 24 for those who had between five and eight years of schooling and 26 for those who had studied for nine years and over $^{15,18}$. Thus, at this stage, questions about chronic diseases, signs and symptoms, sleep problems, drug use, self-assessment of health, smoking and drinking, access to health services, among others, were applied ${ }^{15}$.

In the present study, the variable of interest was the simultaneous consumption of five or more drugs, a condition that characterizes the practice of polypharmacy. A systematic literature review indicated few studies that used numerical definitions of polypharmacy and incorporated the duration of therapy, and a lower frequency of studies that used definitions which considered the health environment ${ }^{19}$. Although there is no universally accepted definition of polypharmacy $^{6,13,19}$, most Brazilian and non-Brazilian studies consider it to mean the use of five or more drugs. Thus, for comparative purposes, we have chosen to adopt this definition. The variable was obtained through the question: "In the last three months have you taken any drugs prescribed by a doctor, or on your own?" (yes or no). To those who answered yes, the question: "How many?" was asked.
For the older adults who answered the questions $(n=2,217)$, the following variables were considered for the analysis of the factors associated with polypharmacy:

- Demographic and socioeconomic status: sex (male and female), age group (65-69, 70-74, 7579 and $\geq 80$ years), skin color/race (white and non-white composed of black, brown (mixed race), yellow (Asian-Brazilian) and indigenous), marital status (with spouse and without spouse), education (no schooling, 1 to 4 , and 5 years or more of schooling), per capita family income in minimum wages $(<1,1$ to 3 and $>3)$, health insurance affiliation (yes and no).

- Nutritional status: Body Mass Index (BMI) calculated with weight and height measurements [weight $(\mathrm{kg}) /$ height $\left(\mathrm{m}^{2}\right)$ ] and classified according to the cutoffs adopted by Lipschitz ${ }^{20}$ : underweight BMI $<22 \mathrm{~kg} / \mathrm{m}^{2}$, normal weight BMI between 22 and $27 \mathrm{~kg} / \mathrm{m}^{2}$ and overweight BMI>27 kg/ $\mathrm{m}^{2}$. The waist circumference (WC) measurement corresponded to the midpoint between the lower edge of the last rib and the iliac crest, classified according to the World Health Organization ${ }^{21}$ : increased $W C \geq 94 \mathrm{~cm}$ and $<102 \mathrm{~cm}$ for men, $\geq 80$ $\mathrm{cm}$ and $<88 \mathrm{~cm}$ for women; greatly increased WC $\geq 102 \mathrm{~cm}$ and $\geq 88 \mathrm{~cm}$ for men and women, respectively.

- Health conditions: self-rated health (very good/ good, fair, poor/very poor), hospitalization in the 12 months prior to the interview (yes and no), number of chronic diseases diagnosed by a doctor ( 0 to 1,2 , and 3 or more), sleep problems (yes and no), loss of appetite (yes and no) and frailty. For the classification of older adults in terms of frailty, the five criteria proposed by Fried et al. ${ }^{16}$ were used to categorize the older adults as frail (positive for three or more criteria), pre-frail (positive for one or two criteria) and not frail (no positive criteria). Certain chronic diseases were also considered: hypertension, diabetes mellitus, heart disease (angina, myocardial infarction or heart attack), stroke/ischemia, depression, arthritis/rheumatism, osteoporosis, malignant tumor/cancer and lung disease. 
The older adults who said they were using drugs, were asked, "How do you access the drugs?", and could respond buy with own money (yes or no), buy with family resources (yes or no) and obtain at Basic Health Unit (yes or no). Thus, from these questions, a variable was created considering only older adults who answered all $(n=1,988)$, with two categories regarding the form of obtaining the drugs (own/ family resources or free), discriminating the different profiles (mutually exclusive categories) to verify the association with polypharmacy.

In the analyzes, the relative percentage frequencies and the prevalence of polypharmacy were estimated according to sociodemographic characteristics, nutritional status and health conditions. The associations between polypharmacy and the variables considered were verified by Pearson's chi-squared test, with a significance level of $5 \%$. Crude prevalence ratios and the respective $95 \%$ confidence intervals $(95 \% \mathrm{CI})$ were also estimated.

Multiple hierarchical analysis was performed in three steps, with all the variables that presented $p<0.20$ in the simple analysis included in the model. Thus, in the first stage, sociodemographic variables were inserted and those with $p<0.05$ remained in the model. In the second stage, the variables related to nutritional status were inserted while the third included the variables related to health conditions, adopting the same criteria described in the first stage.

Statistical analysis was performed using the Stata program, version 14.0 (Stata Corp., College Station, USA). The Fibra Study was approved by the Research Ethics Committee of the Faculty of Medical Sciences of the Universidade Estadual de Campinas (the State University of Campinas) under opinion
No. 208/2007 and registered on the Plataforma Brasil (the Brazil Platform) under CAAE number 39547014.0. 1001.5404.

\section{RESULTS}

The sample of the present study consisted of 2,217 older adults who reported using drugs. The average age of the older adults was 72.4 years $(95 \%$ CI: 72.2-72.7) and 67.6\% were women. The average number of drugs used was 2.9 (95\% CI: 2.8-3.0). The prevalence of polypharmacy was $18.4 \%$ (95\% CI: 16.8-20.0), and was lower in non-whites and those without health insurance at the time of the survey. There was an increase in the prevalence of polypharmacy as schooling increased $(p<0.05)$ (Table 1).

Table 2 shows the prevalence and prevalence ratios according to nutritional status and health conditions. Except for sleep problems and loss of appetite, all the other variables were associated with polypharmacy $(p<0.05)$. The prevalence of polypharmacy according to specific chronic diseases is shown in Figure 1. About 30.0\% of older adults with heart disease, diabetes mellitus and stroke/ CVA/ischemia used five or more drugs at the time of the survey $(p<0.05)$.

The results of the hierarchical regression analysis are shown in Table 3. The prevalence of polypharmacy was significantly lower in non-white people, among those without health insurance, and among those who self-rated their health as very good/good $(p<0.05)$. Obesity, greatly increased waist circumference, and the presence of two or more chronic diseases were positively associated with polypharmacy $(p<0.05)$. 
Table 1. Sample distribution, prevalence and prevalence ratio of polypharmacy in community-dwelling older adults ( $\geq 65$ years) according to sociodemographic variables. Fibra Study, 2008/2009.

\begin{tabular}{|c|c|c|c|c|}
\hline Variables & $\mathrm{n}(\%)$ & Prevalence & $p^{*}$ & $\mathrm{PR}^{* *}(\mathrm{CI} 95 \%)$ \\
\hline Sex & & & 0.094 & \\
\hline Female & $1.498(67.6)$ & 19.4 & & 1 \\
\hline Male & $719(32.4)$ & 16.4 & & $0.85(0.68-1.05)$ \\
\hline Total & 2.217 & 18.4 & & \\
\hline Age range (in years) & & & 0.378 & \\
\hline 65 to 69 & $818(36.9)$ & 17.2 & & 1 \\
\hline 70 to 74 & $705(31.8)$ & 18.7 & & $1.09(0.86-1.38)$ \\
\hline 75 to 79 & $418(18.9)$ & 21.0 & & $1.22(0.94-1.59)$ \\
\hline 80 years or more & $276(12.4)$ & 17.0 & & $0.99(0.71-1.37)$ \\
\hline Skin color (self-reported) & & & $<0.001$ & \\
\hline White & $1.225(55.8)$ & 22.0 & & 1 \\
\hline Non-white & $971(44.2)$ & 13.7 & & $0.62(0.50-0.76)$ \\
\hline Lives with partner & & & 0.946 & \\
\hline Yes & $1.095(49.5)$ & 18.4 & & 1 \\
\hline No & $1.118(50.5)$ & 18.3 & & $0.99(0.82-1.21)$ \\
\hline Schooling (in years of schooling) & & & 0.008 & \\
\hline Never studied & $419(18.9)$ & 13.8 & & 1 \\
\hline 1 to 4 & $1.109(50.1)$ & 18.3 & & $1.32(0.99-1.77)$ \\
\hline 5 or more & $685(30.9)$ & 21.3 & & $1.54(1.14-2.09)$ \\
\hline Family income (MW) & & & 0.001 & \\
\hline$<1$ & $800(23.0)$ & 18.4 & & 1 \\
\hline$\geq 1$ and $\leq 3$ & $1.580(45.4)$ & 15.4 & & $0.83(0.64-1.09)$ \\
\hline$>3$ & $1.097(31.6)$ & 22.2 & & $1.21(0.93-1.56)$ \\
\hline Health plan & & & $<0.001$ & \\
\hline Yes & $877(40.1)$ & 23.9 & & 1 \\
\hline No & $1.310(59.9)$ & 14.7 & & $0.61(0.51-0.75)$ \\
\hline
\end{tabular}

$\mathrm{n}$ : total number of individuals in sample; MW: minimum wage at time of study; * Pearson chi-squared test;**PR: prevalence ratio; CI95\%: confidence interval of $95 \%$.

Table 2. Prevalence and prevalence ratio of polypharmacy in community-dwelling older people ( $\geq 65$ years) according to nutritional status and health conditions. Fiber Study, 2008/2009.

\begin{tabular}{|c|c|c|c|c|}
\hline Variables & $\mathrm{n}(\%)$ & Prevalence & $p$-value ${ }^{*}$ & $\mathrm{PR}^{* *}(\mathrm{CI} 95 \%)$ \\
\hline Body Mass Index (kg / m2) & & & $<0.001$ & \\
\hline Normal weight & $870(39.2)$ & 14.5 & & 1 \\
\hline Underweight & $224(10.1)$ & 11.2 & & $0.77(0.50-1.18)$ \\
\hline Overweight & $1.123(50.7)$ & 22.9 & & $1.58(1.28-1.95)$ \\
\hline Waist circumference & & & $<0.001$ & \\
\hline Normal & $553(24.9)$ & 11.0 & & 1 \\
\hline Increased & $565(25.5)$ & 16.8 & & $1.52(1.10-2.10)$ \\
\hline Greatly increased & $1.099(49.6)$ & 22.9 & & $2.08(1.57-2.75)$ \\
\hline
\end{tabular}


Continuation of Table 2

\begin{tabular}{|c|c|c|c|c|}
\hline Variables & $\mathrm{n}(\%)$ & Prevalence & $p$-value ${ }^{*}$ & $\mathrm{PR}^{* *}(\mathrm{CI} 95 \%)$ \\
\hline Health self-assessment & & & 0.001 & \\
\hline Poor/ very poor & $643(29.2)$ & 22.4 & & 1 \\
\hline Regular & $854(38.7)$ & 18.5 & & $0.83(0.66-1.03)$ \\
\hline Very good / good & $708(32.1)$ & 14.7 & & $0.66(0.51-0.84)$ \\
\hline Hospitalization in the last year & & & $<0.001$ & \\
\hline No & $1.835(83.4)$ & 17.0 & & 1 \\
\hline Yes & $366(16.6)$ & 25.4 & & $1.49(1.18-1.88)$ \\
\hline Number of chronic diseases & & & $<0.001$ & \\
\hline 0 to 1 & $624(28.6)$ & 5.8 & & 1 \\
\hline 2 & $621(28.4)$ & 13.8 & & $2.40(1.63-3.54)$ \\
\hline 3 or more & $938(43.0)$ & 29.6 & & $5.14(3.63-7.27)$ \\
\hline Frailty & & & 0.010 & \\
\hline Not frail & $884(39.9)$ & 16.1 & & 1 \\
\hline Pre-frail & $1.166(52.6)$ & 19.2 & & $1.20(0.97-1.48)$ \\
\hline Frail & $165(7.5)$ & 25.4 & & $1.58(1.12-2.24)$ \\
\hline Sleep problems & & & 0.101 & \\
\hline Yes & $1.124(50.7)$ & 19.7 & & 1 \\
\hline No & $1.091(49.3)$ & 17.0 & & $0.86(0.71-1.05)$ \\
\hline Loss of appetite & & & 0.637 & \\
\hline Yes & $558(25.4)$ & 19.2 & & 1 \\
\hline No & $1.636(74.6)$ & 18.3 & & 0.95 (0.76-1.19) \\
\hline
\end{tabular}

n: total individuals in sample;* Pearson's chi-squared test;**PR: prevalence ratio; CI95\%: 95\% confidence interval.

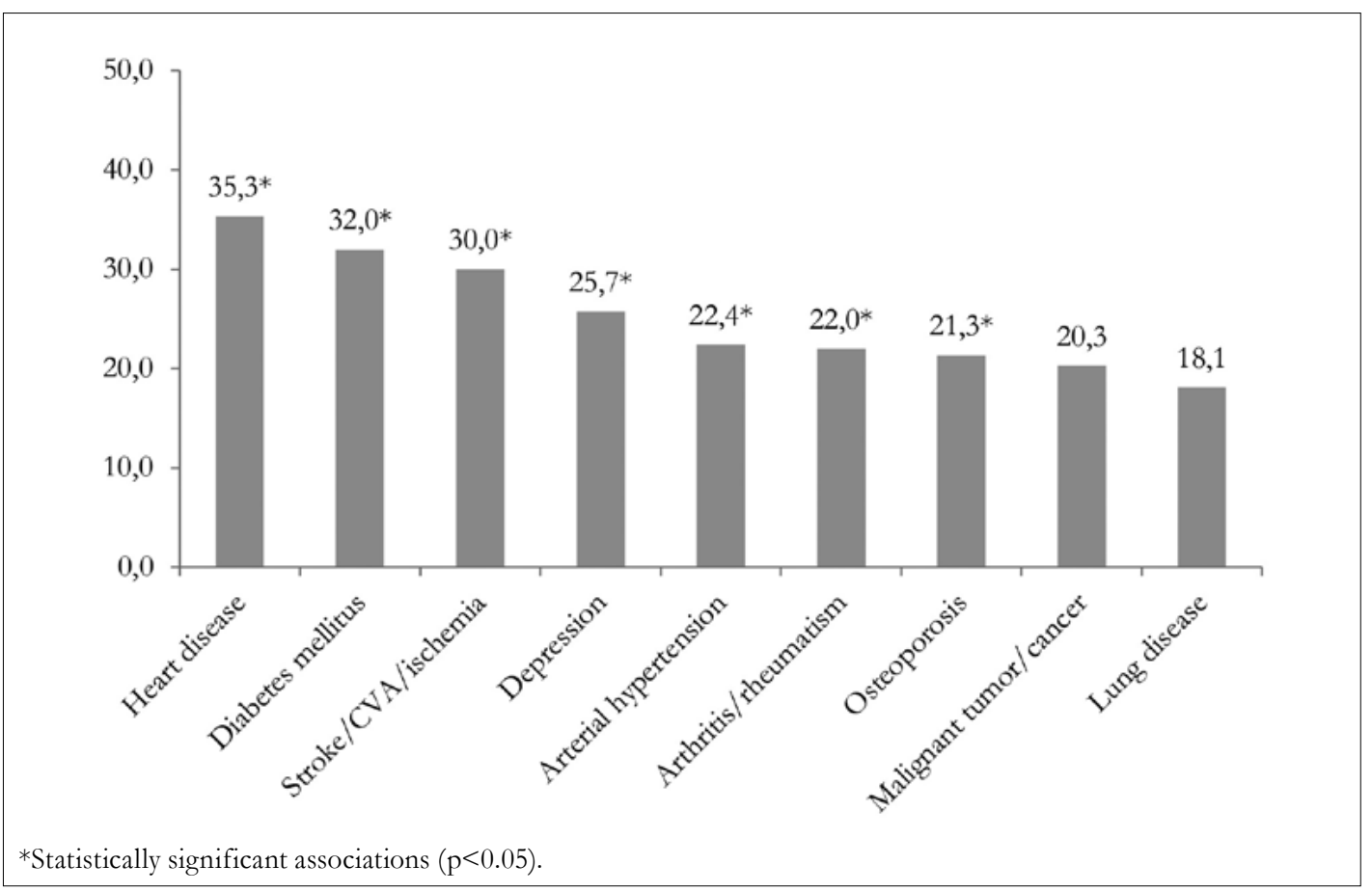

Figure 1. Prevalence of polypharmacy in older adults ( $\geq 65$ years), according to the presence of chronic diseases. Fibra Study, 2008/2009. 
Table 3. Poisson regression multiple hierarchical model for the association between polypharmacy and sociodemographic variables, nutritional status and health conditions in community-dwelling older adults $(\geq 65$ years). Fibra Study, 2008/2009.

\begin{tabular}{|c|c|c|c|}
\hline Variables & $\begin{array}{l}\text { First stage } \\
{ }^{*} \mathrm{PR}_{\text {Adjusted }} \\
\left(\mathrm{CI}_{95 \%}\right) \\
\end{array}$ & $\begin{array}{l}\text { Second stage } \\
{ }^{* *} \mathrm{PR}_{\text {Adjusted }} \\
\left(\mathrm{CI}_{95 \%}\right) \\
\end{array}$ & $\begin{array}{l}\text { Third stage } \\
{ }^{* * *} \mathrm{PR}_{\text {Adjusted }} \\
\left(\mathrm{CI}_{95 \%}\right)\end{array}$ \\
\hline \multicolumn{4}{|l|}{ Skin color } \\
\hline White & 1 & 1 & 1 \\
\hline Not white & $0.70(0.56-0.86)$ & $0.72(0.58-0.90)$ & $0.70(0.56-0.87)$ \\
\hline \multicolumn{4}{|l|}{ Health insurance } \\
\hline Yes & 1 & 1 & 1 \\
\hline No & $0.67(0.55-0.82)$ & $0.67(0.55-0.82)$ & $0.70(0.57-0.86)$ \\
\hline \multicolumn{4}{|c|}{ Body Mass Index (kg / m2) } \\
\hline Normal weight & & 1 & 1 \\
\hline Underweight & & $0.94(0.59-1.50)$ & $0.93(0.58-1.49)$ \\
\hline Overweight & & $1.36(1.06-1.75)$ & $1.21(0.94-1.56)$ \\
\hline \multicolumn{4}{|c|}{ Waist circumference } \\
\hline Normal & & 1 & 1 \\
\hline Increased & & $1.28(0.90-1.83)$ & $1.20(0.84-1.72)$ \\
\hline Greatly increased & & $1.54(1.08-2.20)$ & $1.32(0.92-1.90)$ \\
\hline \multicolumn{4}{|c|}{ Health self-assessment } \\
\hline Poor/very poor & & & 1 \\
\hline Regular & & & $0.89(0.71-1.13)$ \\
\hline Very good/good & & & $0.76(0.58-0.99)$ \\
\hline \multicolumn{4}{|c|}{ Number of chronic diseases } \\
\hline 0 to 1 & & & 1 \\
\hline 2 & & & $2.24(1.52-3.31)$ \\
\hline 3 or more & & & $4.22(2.96-6.02)$ \\
\hline
\end{tabular}

*Adjusted by sociodemographic variables;**Adjusted by sociodemographic variables and nutritional state; ***Adjusted for sociodemographic, nutritional and health status variables; PR: Prevalence ratio adjusted by Poisson multiple regression.

Regarding the form of drug acquisition, the frequencies of polypharmacy among those who reported obtaining their drug at the Basic Health Unit and through their own/family resources were $20.3 \%$ and $13.5 \%$, respectively ( $p<0.001)$. Adjusting for sex, age and number of chronic diseases, the association was at the limit of statistical significance $(\mathrm{PR}=1.27$; 95\% CI: 1.00-1.61) (data not shown in table).

\section{DISCUSSION}

In the present study, the prevalence of polypharmacy was $18.4 \%$ for older adults aged $\geq 65$ years. Considering the same definition adopted in this study (use of five or more drugs), Brazilian surveys that used the age group of 60 years or older detected prevalences of $10.3 \%$ in Cuiabá (Minas Gerais) ${ }^{22}, 28.0 \%$ in Goiânia (Goiás) ${ }^{23}$ and 32.0\% in Florianópolis (Santa Catarina) ${ }^{24}$. In the National Survey on Access, Use and Promotion of the Rational Use of Drugs (or PNAUM), the prevalence of polypharmacy was estimated at $18.0 \%{ }^{6}$. Among the $\geq 65$-year-old segment, the prevalence of the concomitant use of five or more drugs was $36.0 \%$ in the city of São Paulo, according to the $\mathrm{SABE}^{25}$ Study, 39.0\% in the United States in the National Health and Nutrition Examination Survey ${ }^{26}$, 44.0\% 
in Sweden, in a three-year prospective cohort study ${ }^{1}$, and $69.0 \%$ in Canada, with data from the National Prescription Drug Utilization Information System ${ }^{27}$.

Comparisons between these prevalences should be made with caution, as the differences observed in drug use studies may be related to factors such as the recall period, age group, access to health services, the supply and prescription of drugs in different locations, as well as the context of the period in which the study was conducted, among others.

No differences were observed in the prevalence of polypharmacy by sex, contradicting the results of other studies. Considering the age group 65 years or older, women presented odds ratios of 1.80 (95\%CI: $1.20-2.60)$ in the city of São Paulo ${ }^{25}$ and 1.28 (95\% CI:1.27-1.29) in Sweden ${ }^{1}$. Differences in sex were also observed in older adults aged 60 years and over, with a higher prevalence in women in Florianópolis ${ }^{24}$, Goiânia $^{23}$ and Brazil-wide (20.1\% versus $\left.15.6 \%\right)^{6}$. Therefore, the relationship between polypharmacy and sex in the older adult population needs to be further clarified.

There was also no difference in the prevalence of polypharmacy in relation to age group, contradicting the findings of other studies ${ }^{23,24}$. In the PNAUM study, the prevalence of polypharmacy was higher in the 70 to 79 age group, compared to the 60 to 69 group, but there was no statistical difference for the oldest older adults ( $\geq 80$ years old $)^{6}$. In Sweden, a three-year follow-up study (age $\geq 65$ years) found differences in the prevalence of polypharmacy: $32.8 \%$ (65 to 74 years), $53.0 \%$ (75 to 84 years), $65.5 \%$ ( 85 to 94 years) and $67.0 \%$ ( $\geq 95$ years) ${ }^{1}$.

It should be considered that the selecting of older people without cognitive impairment, as well as the request that they get to the data collection site by their own means, may have inserted some selection bias into the study due to the majority who participated in the study being physically, emotionally and cognitively robust at the time it was carried out.

In the present study, the prevalence of polypharmacy was significantly lower among nonwhites, unlike the results of other studies that found no association between polypharmacy and skin color $^{23,28}$. This could indicate less access to diagnosis and treatment in health services, and also lower purchasing power when obtaining the drugs, as well as the lower survival rates of such older people.

The prevalence of polypharmacy was lower among older adults who did not have health insurance. The PNAUM survey also identified a lower prevalence of polypharmacy in older adults who did not have private health insurance $(16.8 \% \text { versus } 22.2 \%)^{6}$. In the city of São Paulo, the use of five or more drugs was lower in older adults treated by the public health network ${ }^{25}$. In Cuiabá (Mato Grosso), on the other hand, older adults who used public health services were more polymedicated ${ }^{22}$. Chronic diseases affect older people and people with low purchasing power, conditions that result from less access to and use of health services ${ }^{29}$. According to the SABE Study, about $70.0 \%$ of older adults without health insurance had no schooling and $58.7 \%$ of women and $81.6 \%$ of men received less than one minimum wage. Regarding the use of services, $51.7 \%$ of older adults without a health plan waited more than 90 days between the scheduling of an appointment and the appointment itself, $74.6 \%$ waited more than one hour to be seen, and $61.3 \%$ did not undergo or underwent only part of the exams requested after an appointment ${ }^{30}$.

Greater levels of schooling were not associated with a higher prevalence of polypharmacy, corroborating the findings of other studies which did not observe a statistical association between schooling and excessive drug use ${ }^{6,22-24}$. In the SABE study, no significant association was found between polypharmacy and educational level, but a higher prevalence was identified among older adults who belonged to the upper tercile of minimum wage income distribution $(37.2 \%)^{25}$. In contrast to the results of this study, in a prospective cohort of Swedish older adults, there was a lower prevalence (35.6\%) and incidence (17.9/100 person-years) of polypharmacy among those with a higher education ${ }^{1}$.

The prevalence of polypharmacy was greater in the subgroups of older adults with waist circumference classified as greatly increased, and in those who were overweight. A study with older people from Goiânia (Goiás) ${ }^{23}$ found, in bivariate analysis, a higher prevalence of polypharmacy in those with a 
greatly increased waist circumference (34.6\%). In the hierarchical model, polypharmacy was higher among the obese. Data from the PNAUM showed that $25.4 \%$ of obese older adults were polymedicated, a significantly higher rate than was estimated for those classified as underweight or normal weight ${ }^{6}$. A crosssectional study conducted in European countries (older adults $\geq 75$ years) found a higher risk of hyperpharmacy ( $\geq 10$ drugs) among obese individuals ${ }^{31}$. Obesity is a risk factor for the development of comorbidities and is associated with metabolic syndrome, which comprises a set of cardiovascular risk factors such as hypertension, diabetes, insulin resistance, hypercholesterolemia and central obesity, defined as the measurement of waist circumference ${ }^{32}$. The higher drug consumption among obese older adults or those with higher central fat deposition may therefore be due to comorbidities and metabolic changes associated with these conditions, as well as changes caused by body fat in drug absorption, distribution and metabolism? ${ }^{7}$.

The simultaneous consumption of five or more drugs was lower among older adults who considered their health very good/good, compared to those who considered it poor/very poor. According to PNAUM, the prevalence of polypharmacy was $11.6 \%$ in older adults who perceived their health as very good/ good, increasing to $22.4 \%$ and $36.8 \%$ among those who responded that it was fair and poor/very poor, respectively ${ }^{6}$. In the Epifloripa Older Adults study, the rate of polypharmacy was almost twice as high in those who negatively self-rated their health ${ }^{24}$. In Goiânia (Goiás), older people who considered their health to be poor were more polymedicated than those who answered very good/good ${ }^{23}$. A population-based survey of older people from Campinas (São Paulo) found that poor/very poor self-rated health was associated with worse living conditions and health and emotional aspects, such as a higher number of chronic diseases, health problems and limitations, and the absence of feelings of happiness and vitality ${ }^{33}$. Self-rated health status is an important indicator of morbidity and use of services, especially in older adults $^{33}$. The accumulation of chronic diseases causes damage to physical health and demands greater use of drugs, which can affect individual well-being and impose a reorganization in the routine of older adults.
Older adults with two or more chronic diseases had a higher prevalence of polypharmacy. Other studies have indicated that the practice of polypharmacy increases with the number of chronic diseases ${ }^{6,23}$. In Goiannia, the prevalence of the concomitant use of five or more drugs was $48.2 \%$ and $57.9 \%$ among older adults who had two or three or more chronic diseases, respectively. ${ }^{23}$. In Swedish older people (age $\geq 65$ years), the prevalence of polypharmacy increased sharply with the number of chronic diseases, from $28.6 \%$ (one) to $45.4 \%$ (two) and $59.9 \%$ (three), reaching $87.2 \%$ among those with five or more diseases ${ }^{1}$.

Older adults diagnosed with heart disease, diabetes mellitus, stroke/CVA/ ischemia, depression, hypertension, arthritis/rheumatism and osteoporosis had a higher prevalence of polypharmacy. In the SABE study a higher prevalence of polypharmacy was observed in older adults who reported diabetes, heart problems, rheumatic disease and hypertension ${ }^{25}$. According to the PNAUM findings, high blood pressure, diabetes, heart disease, lung disease, high cholesterol, rheumatism and depression were associated with polypharmacy ${ }^{6}$.

In relation to the acquisition of drugs, among the older adults who reported such information, a higher percentage of polypharmacy was observed, within the limit of significance, among those who acquired their drugs from a Basic Health Unit (free of charge), which may indicate both greater access to drugs for individuals with chronic conditions receiving care in public health services, as well as for those who have a medical health plan, since the National Drugs Policy, through the National List of Essential Drugs (Rename) ${ }^{6,34}$, guarantees the free of charge access to a group of drugs used by older adults with the most frequent chronic conditions ${ }^{6}$.

National Health Survey (or PNS) data for the adult population as a whole reveal that $81.4 \%$ of total hypertensive patients were receiving drug-based treatment, $92.2 \%$ of those over 75 years of age; $80.2 \%$ and $52.0 \%$ of those who reported suffering from diabetes and depression, respectively, and $81.5 \%$ of those with asthma ${ }^{35}$.

In addition to access to the drugs necessary for the treatment of the various chronic conditions that most often affect older adults, constant medical 
monitoring should be provided for the reevaluation of the clinical profile of the individual and adjustments, if necessary, to a prescription. The training of the multidisciplinary health team on the adoption of strategies for the rational use of $\mathrm{drugs}^{36}$ is also important, to minimize health risks and improve quality of life.

Drug therapy is essential for the control and treatment of the diseases and comorbidities that manifest themselves with aging, however, the unnecessary and abusive use of drugs needs to be addressed through alternative strategies to often essentially prescriptive biomedical practices. The joint work of physicians and pharmacists is of fundamental importance in many cases. In addition, in the context of public health services, the use of Complementary and Integrative Medicine, offered free of charge in over 3,000 municipalities, $88 \%$ of which is provided via Primary Health Care (PHC) establishments of the Unified Health System ${ }^{37}$ should be considered, as well as multidisciplinary care involving nutritionists, physiotherapists, occupational therapists and physical educators, among others with a broad and more resolute approach. These care strategies can contribute to the reduction of polypharmacy and improve the quality of life of older adults.

Among the limitations of the present study is the fact that the data relate to the period from 2008 to 2009. In terms of nutritional status, it should be noted that BMI does not differentiate muscle tissue from adipose tissue, nor does it evaluate the distribution of body fat. In addition, the progressive loss of lean mass in older adults affects its validity as an indicator of adiposity, regardless of changes in weight ${ }^{38}$. Also, information on the amount of drugs used may be influenced by memory bias, and the specific drugs used by the polymedicated older adults were not verified. In addition, the healthier profile of the selected older adults may have underestimated the prevalence of polypharmacy.

In the Fibra study, men and women from four age groups (65-69, 70-74, 75-79 and 80 years and older) were recruited in proportion to those observed in the same age and sex groups of the urban population of the selected cities at the time of the study. However, discrepancies observed between the estimated and the obtained quotas may limit the generalization of the results to the wider population ${ }^{15}$. Among the strengths of the study is the methodological rigor of the Fibra Study, designed to obtain a broad set of information on the health conditions of older adults ${ }^{15}$.

\section{CONCLUSION}

The results of the present study indicated that $18.4 \%$ of older adults used five or more drugs. The segments of white older adults, who had health insurance, were overweight, had a greatly increased waist circumference measurement, who evaluated their health as more negative and who had two or more chronic diseases, were more likely to practice polypharmacy. It is important to identify those subgroups of older adults with a higher prevalence of polypharmacy, for more frequent monitoring and evaluations, to avoid any problems related to the interference of drugs in the therapeutic results and quality of life of such adults.

There was also a higher percentage within the limits of statistical significance in those who reported acquiring drugs from Basic Health Units, regardless of sex, age and number of chronic diseases, which may indicate greater access to drugs in the Unified Health System, but also little appreciation of other non-drug therapeutic practices for the care of older adults, even in the public health service.

Finally, it should be pointed out that there has been a notable expansion of health needs due to the rapid and progressive aging of the Brazilian population. In this sense, health care for older adults needs to consider multidimensional needs in a more integrated manner. The results of this study can be used to guide joint actions between doctors, pharmacists and other health professionals for the treatment of older adults, in order to reconcile the necessary use of drugs with health conditions and other non-pharmacological therapies.

Edited by: Tamires Carneiro Oliveira Mendes 


\section{REFERENCES}

1. Morin L, Johnell K, Laroche ML, Fastbom J, Wastesson JW. The epidemiology of polypharmacy in older adults: register-based prospective cohort study. Clin Epidemiol. 2018;10:289-98.

2. Theme Filha MM, Souza Junior PRB, Damacena GN, Szwarcwald CL. Prevalência de doenças crônicas não transmissíveis e associação com autoavaliação de saúde: Pesquisa Nacional de Saúde, 2013. Rev Bras Epidemiol. 2015;18(2):83-96.

3. Muniz ECS, Goulart FC, Lazarini CA, Marin MJS. Análise do uso de medicamentos por idosos usuários de plano de saúde suplementar. Rev Bras Geriatr Gerontol. 2017;20(3):375-87.

4. Romano-Lieber NS, Corona LP, Marques LFG, Secoli SR. Sobrevida de idosos e exposição à polifarmácia no município de São Paulo: Estudo SABE. Rev Bras Epidemiol. 2018;21(Suppl 2):e180006 [11p.].

5. Carneiro JA, Ramos GCF, Barbosa ATF, Medeiros SM, Lima CA, Costa FM, et al. Prevalência e fatores associados à polifarmácia em idosos comunitários: estudo epidemiológico de base populacional. Medicina (Ribeirão Preto, Online). 2018;51(4):254-64.

6. Ramos LR, Tavares NUL, Bertoldi AD, Farias MR, Oliveira MA, Luiza VL, et al. Polifarmácia e polimorbidade em idosos no Brasil: um desafio em saúde pública. Rev Saúde Pública. 2016;50(supl 2):1-9.

7. Cantlay A, Glyn T, Barton N. Polypharmacy in the elderly. InnovAiT. 2016;9(2):69-77.

8. Lutz BH, Miranda VIA, Bertoldi AD. Inadequação do uso de medicamento entre idosos em Pelotas, RS. Rev Saúde Pública. 2017;51:1-12.

9. Costa GM, Oliveira MLC, Novaes MRCG. Fatores associados à polifarmacoterapia entre idosos assistidos pela estratégia da saúde da família. Rev Bras Geriatr Gerontol. 2017;20(4):528-37.

10. Anacleto TA. Medicamentos potencialmente inadequados para idosos. Boletim ISMP. 2017;7(3).1-8.

11. Prado MAMB, Francisco PMSB, Bastos TF, Barros MBA. Uso de medicamentos prescritos e automedicação em homens. Rev Bras Epidemiol. 2016;19(3):594-608.

12. Manso MEG, Biffi ECA, Gerardi TJ. Prescrição inadequada de medicamentos a idosos portadores de doenças crônicas em um plano de saúde no munícipio de São Paulo, Brasil. Rev Bras Geriatr Gerontol. 2015;18(1):151-64.

13. Secoli SR. Polifarmácia: interações e reações adversas no uso de medicamentos por idosos. Rev Bras Enferm. 2010;63(1):136-40.
14. Rozenfeld S, Fonseca MJM, Acurcio FA. Drug utilization and polypharmacy among the elderly: a Survey in Rio de Janeiro City, Brazil. Rev Panam Salud Publica. 2008;23(1):34-43.

15. Neri AL, Yassuda MS, Araújo LF, Eulálio MC, Cabral BE, Siqueira MEC, et al. Metodologia e perfil sociodemográfico, cognitivo e de fragilidade de idosos comunitários de sete cidades brasileiras: Estudo FIBRA. Cad Saúde Pública. 2013;29(4):778-92.

16. Fried LP, Tangen CM, Walston J, Newman AB, Hirsch C, Gottdiener J, et al. Frailty in older adults: evidence for a phenotype. J Gerontol Ser A Biol Sci Med Sci. 2001;56:146-56.

17. Ferrucci L, Guralnik JM, Studenski S, Fried LP, Cutler Jr. GB, Walston JD. Designing randomized, controlled trials aimed at preventing or delaying functional decline and disability in frail, older persons: a consensus report. J Am Geriatr Soc. 2004;52(4):625-34.

18. Brucki SMD, Nitrini R, Caramelli P, Bertolucci PHF, Okamoto IH. Sugestões para o uso do mini-exame do estado mental no Brasil. Arq Neuropsiquiatr. 2003;61(3):778-81.

19. Masnoon N, Shakib S, Kalisch-Ellett L, Caughey GE. What is polypharmacy?: a systematic review of definitions. BMC Geriatrics. 2017;17:1-10.

20. Cervi A, Franceschini SCC, Priore SE. Análise crítica do uso do índice de massa corporal para idosos. Rev Nutr. 2005;18(6):765-75.

21. World Health Organization. Obesity: preventing and managing the global epidemic. Geneva: WHO; 2000.

22. Almeida NA, Reiners AAO, Azevedo RCS, Silva AMC, Cardoso JDC, Souza LC. Prevalência e fatores associados à polifarmácia entre os idosos residentes na comunidade. Rev Bras Geriatr Gerontol. 2017;20(1):143-53.

23. Silveira EA, Dalastra L, Pagotto V. Polifarmácia, doenças crônicas e marcadores nutricionais em idosos. Rev Bras Epidemiol. 2014;17(4):818-29.

24. Pereira KG, Peres MA, Iop D, Boing AC, Boing AF, Aziz M, et al. Polifarmácia em idosos: um estudo de base populacional. Rev Bras Epidemiol. 2017;20(2):335-44.

25. Carvalho MFC, Romano-Lieber NS, BergstenMendes G, Secoli SR, Ribeiro E, Lebrão ML, et al. Polifarmácia entre idosos do município de São Paulo Estudo SABE. Rev Bras Epidemiol. 2012;15:817-27.

26. Kantor ED, Rehm CD, Haas JS, Chan AT, Giovannucci EL. Trends in prescription drug use among adults in the United States from 1999-2012. JAMA. 2015;314(17):1818-31. 
27. McPherson M, Ji H, Hunt J, Ranger R, Gula C. Medication Use among canadian Seniors. Healthc Q. 2012;15(4):15-8.

28. Sales AS, Sales MGS, Casotti CA. Perfil farmacoterapêutico e fatores associados à polifarmácia entre idosos de Aiquara, Bahia, em 2014. Epidemiol Serv Saúde. 2017;26(1):121-32.

29. Malta DC, Stopa SR, Iser BPM, Bernal RTI, Claro RM, Nardi ACF, et al. Fatores de risco e proteção para doenças crônicas por inquérito telefônico nas capitais brasileiras, Vigitel 2014. Rev Bras Epidemiol. 2015;18(Supl.2):238-55.

30. Hernandes ESC, Lebrão ML, Duarte YAO, Santos JLF. Idosos com e sem plano de saúde e características socioepidemiológicas associadas. Rev Saúde Pública. 2012;46(6):1030-8.

31. Rieckert A, Trampisch US, Klaaben-Mielke R, Drewelow E, Esmail A, Johansson T, et al. Polypharmacy in older patients with chronic diseases: a cross-sectional analysis of factors associated with excessive polypharmacy. BMC Fam Pract. 2018;19:1-9.

32. Sociedade Brasileira de Cardiologia. I Diretriz Brasileira de Diagnóstico e Tratamento da Síndrome Metabólica. Arq Bras Cardiol. 2005;84(Suppl 1):1-28.
33. Borim FSA, Neri AL, Francisco PMSB, Barros MBA. Dimensões da autoavaliação de saúde em idosos. Rev Saúde Pública. 2014;48(5):714-22.

34. Bermudez JAZ, Esher A, Osorio-de-Castro CGS, Vasconcelos DMM, Chaves GC, Oliveira MA, et al. Assistência farmacêutica nos 30 anos do SUS na perspectiva da integralidade. Ciênc Saúde Colet. 2018;23(6):1937-51.

35. Tavares NUL, Costa KS, Mengue SS, Vieira MLFP, Malta DC, Silva Júnior JB. Uso de medicamentos para tratamento de doenças crônicas não transmissíveis no Brasil: resultados da Pesquisa Nacional de Saúde, 2013. Epidemiol Serv Saúde. 2015;24(2):315-23.

36. Brasil. Ministério da Saúde. Uso racional de medicamentos: temas selecionados. Brasília, DF: MS; 2012. (Série A. Normas e Manuais Técnicos).

37. Brasil. Ministério da Saúde, Secretaria de Atenção à Saúde. Política Nacional de Práticas Integrativas e Complementares no SUS: atitude de ampliação de acesso. Brasília, DF: MS; 2015.

38. Associação Brasileira para o Estudo da Obesidade e da Síndrome Metabólica. Diretrizes brasileiras de obesidade 2016 [Internet]. São Paulo: ABESO; 2016 [acesso em 05 mar. 2019]. Disponível em: http://www. abeso.org.br/uploads/downloads/92/57fccc403e5da.pdf 